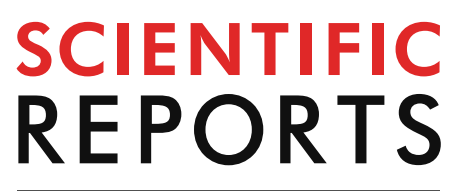

natureresearch

Check for updates

\title{
OPEN Cover crops and chicken grazing in a winter fallow field improve soil carbon and nitrogen contents and decrease methane emissions
}

\author{
Huabin Zheng ${ }^{1}{ }^{1}$, Linhong Zhou ${ }^{1}$, Jiabing Wei ${ }^{1}$, Qiyuan Tang ${ }^{1}$, Yingbin Zou ${ }^{1}$, Jianwu Tang ${ }^{2 \bowtie} \&$ \\ Huaqin $\mathrm{Xu}^{1 \bowtie}$ \\ Using symbiotic farming methods [cover crops and chicken grazing $(+\mathrm{C})$ ] in a winter fallow field, we \\ found that the soil organic matter and total nitrogen of the $+C$ treatment were $5.2 \%$ and $26.6 \%$ higher, \\ respectively, than those of a treatment with cover crops and no chicken grazing $(-\mathrm{C})$. The annual rice \\ grain yield of the $+\mathrm{C}$ treatment was $3.8 \%$ higher than that of the $-\mathrm{C}$ treatment and $12.3 \%$ higher than \\ that of the bare fallow field (CK), while the annual $\mathrm{CH}_{4}$ emissions of the $+\mathrm{C}$ treatment were $26.9 \%$ \\ lower than those of the - $\mathrm{C}$ treatment and $10.6 \%$ lower than those of the CK treatment. The 100- \\ year global warming potential of the $+C$ treatment was $6.2 \%$ lower than that of the $-C$ treatment. \\ Therefore, the use of winter cover crops and chicken grazing in a winter fallow field was effective at \\ reducing $\mathrm{CH}_{4}$ emissions and significantly improving soil nutrients and rice yield.
}

South China is a main double-season rice production area ${ }^{1}$. Intensification of rice cultivation may pose risks to the long-term sustainability and productivity of rice paddies ${ }^{2}$. At present, the development of paddy field farming systems is faced with outstanding problems and challenges such as reduction of ripening system, excessive input, waste of resources, weakening of cultivated land, fragile foundation and reduced efficiency ${ }^{3,4}$. Therefore, there is an urgent need to develop a soil management practice that will improve soil quality and eliminate the risks associated with intensified double rice cropping in southern China.

In south China, the paddy field has a large winter leisure area, most areas have a suitable climate and abundant resources. However, the multiple cropping index is low, which is a great waste of natural resources and reduces soil fertility. Green manuring is considered as an important soil management practice with the potential to maintain soil organic matter (SOM) content and reduce the dependence on mineral fertilizers ${ }^{5}$. The crops used in green manuring are generally high biomass yielding and $\mathrm{N}$-fixing plant species ${ }^{6,7}$. In addition, the growing period of the cover crop does not lead to competition over land for rice production. The growth duration of the double rice cropping season after transplantation lasts from April to October ${ }^{8}$, while November to March (the winter season) of the following year can be used to plant green manure in most regions in southern China. Green manure returning to the field has improved soil physical and chemical and biological properties, increased crop yield, and controlled paddy field's weed and other functions. The cultivation of winter cover crops as green manure has also been strongly recommended in rice paddy soil in temperate-zone countries, such as Korea and Japan ${ }^{9}$. Similarly, in southern China, farmers often seed cover crops after rice harvest and then incorporate them in situ as green manure before transplanting rice in the next season. However, the low economic benefits of cover cropping often prevent the large deployment of this practice. Furthermore, the addition of cover crops as green manure could stimulate $\mathrm{CH}_{4}$ emissions in flooded paddy soil ${ }^{10-13}$. Therefore, additional studies are needed to improve soil fertility, including SOM and liable nitrogen, while reducing $\mathrm{CH}_{4}$ emissions for cover cropping management.

Symbiotic farming technologies, such as rice-fish farming and rice-duck farming, could significantly reduce greenhouse gas emissions (as reviewed by Zheng et al. ${ }^{14}$ ) in addition to the benefits that the symbiotic systems have on rice paddies ${ }^{14,15}$. In this study, it was found that the cover crops (high biomass yield and protein) used for chicken grazing could reduce the cost of feeding the chickens. Any remaining grass is eaten by the chickens, and 


\begin{tabular}{|c|c|c|c|c|c|c|c|c|c|}
\hline \multirow[b]{2}{*}{ Treatment } & \multicolumn{3}{|c|}{ Soil organic carbon $\left(\mathrm{g} \mathrm{kg}^{-1}\right)$} & \multicolumn{3}{|c|}{ Soil total nitrogen $\left(\mathrm{g} \mathrm{kg}^{-1}\right)$} & \multicolumn{3}{|c|}{ C:N ratio } \\
\hline & GM & ER & LR & GM & ER & LR & GM & ER & LR \\
\hline$+\mathrm{C}$ & $15.20 \mathrm{a}$ & $14.32 \mathrm{a}$ & $14.74 \mathrm{a}$ & $3.24 \mathrm{a}$ & $2.80 \mathrm{a}$ & $2.50 \mathrm{a}$ & $4.69 \mathrm{c}$ & $5.11 \mathrm{~b}$ & $5.88 \mathrm{~b}$ \\
\hline$-\mathrm{C}$ & $14.10 \mathrm{a}$ & $13.63 \mathrm{a}$ & $14.34 \mathrm{a}$ & $2.30 \mathrm{~b}$ & $2.38 \mathrm{a}$ & $2.06 \mathrm{~b}$ & $6.12 \mathrm{~b}$ & $5.72 \mathrm{~b}$ & $6.97 \mathrm{~b}$ \\
\hline $\mathrm{CK}$ & $12.41 \mathrm{~b}$ & $11.91 \mathrm{~b}$ & $12.53 \mathrm{~b}$ & $1.05 \mathrm{c}$ & $1.36 \mathrm{~b}$ & $1.18 \mathrm{c}$ & $11.85 \mathrm{a}$ & $8.79 \mathrm{a}$ & $10.61 \mathrm{a}$ \\
\hline
\end{tabular}

Table 1. Variation in the soil organic carbon and total nitrogen among the three treatments [cover crops with chicken grazing $(+C)$, cover crops with no chicken grazing $(-C)$, and bare fallow field $(C K)]$. GM, ER, and LR were the green manure return, early rice harvest and late rice harvest stages, respectively; the C:N ratio was the ratio between the soil organic matter and soil total nitrogen. Different lowercase letters in the same column among the different treatments indicate significant differences at the 0.05 level.

the manure produced further enhances the soil. Green manure straw is good chicken feed as it has high protein. With moderate chicken intensity, the green manure continued to grow after the chicken were sold. And finial the mixture with chicken manure and straw enhances the soil. This system of cover crop planting and chicken grazing was relatively simple to maintain, reducing labor costs. The free-range chickens are then sold before the main crops are planted, thus increasing the economic outputs. In this study, using a symbiotic farming practice with cover crops with chicken grazing in a winter fallow field, we aim to (i) improve soil carbon and nitrogen availability, (ii) increase rice grain yield, and (iii) reduce $\mathrm{CH}_{4}$ emissions in the rice growing season.

\section{Results}

Soil organic carbon and nitrogen. The soil organic carbon content in the plot with cover crops was significantly higher than that in the bare fallow field (CK, Table 1). The soil organic carbon in the cover crop and chicken grazing $(+\mathrm{C})$ treatment was $5.2 \%(3 \sim 8 \%)$ higher than that in the treatment with cover crops and no chicken grazing $(-\mathrm{C})$. Similarly, the soil total nitrogen content in the plot with cover crops was significantly higher than that in the CK plot (Table 1). The soil total nitrogen in the $+\mathrm{C}$ treatment was $26.6 \%(18 \sim 41 \%)$ higher than that in the $-\mathrm{C}$ treatment. The $\mathrm{C}: \mathrm{N}$ ratio of the $\mathrm{CK}$ was significantly higher than that of the plot with cover crops, and the C:N ratio in the $+\mathrm{C}$ treatment was $16.5 \%(11 \sim 23 \%)$ lower than that in the $-\mathrm{C}$ treatment, while no significant difference was observed between the $+\mathrm{C}$ and $-\mathrm{C}$ treatments in the rice planting seasons. Therefore, chicken grazing in the cover crop plots increased the soil organic carbon and total nitrogen.

Soil microbial carbon and nitrogen. The soil microbial carbon and nitrogen contents in the plot with cover crops were higher than those in the bare fallow field (CK, Fig. 1a,b). The peak of the soil microbial carbon and nitrogen contents occurred 120 days after chicken grazing, reaching 478.6 and $19.1 \mathrm{mg} \mathrm{kg}^{-1}$ in the $+\mathrm{C}$ treatment and 433.9 and $23.5 \mathrm{mg} \mathrm{kg}^{-1}$, in the $-\mathrm{C}$ treatment, respectively. There was a significant difference among the $+\mathrm{C},-\mathrm{C}$, and CK treatments. In addition, the soil microbial C: $\mathrm{N}$ ratio in the cover crop plot was not higher than that in the $\mathrm{CK}$ plot, while in the late rice harvesting stage (347 days after chicken grazing), the soil microbial carbon and nitrogen in the $+\mathrm{C}$ and $-\mathrm{C}$ treatments were higher than that in the CK plot (Fig. 1c). The results suggest that in situ chicken manure input to the plots with cover crops and chickens increases the carbon and nitrogen sources available to the soil microorganisms, which may also stimulate cover crop growth and development, and further increase root exudates for the soil microorganisms.

Dissolved organic carbon and nitrogen. The dissolved organic carbon and nitrogen (DOC and DON, respectively) in the plots with cover crop were higher than those in the bare fallow field (CK, Fig. 2a,b). Similarly, the peak DOC was observed 170 days after chicken grazing, reaching $272.7 \mathrm{mg} \mathrm{kg}^{-1}$ for the $+\mathrm{C}$ treatment and $247.7 \mathrm{mg} \mathrm{kg}^{-1}$ for the $-\mathrm{C}$ treatment. The peak DON occurred 120 days after chicken grazing, reaching $964.8 \mathrm{mg} \mathrm{kg}^{-1}$ for the $+\mathrm{C}$ treatment and $852.8 \mathrm{mg} \mathrm{kg}^{-1}$ for the $-\mathrm{C}$ treatment. A significant difference was found among the $+\mathrm{C},-\mathrm{C}$, and $\mathrm{CK}$ treatments. The dissolved organic $\mathrm{C}: \mathrm{N}$ ratio in the cover crop plots was lower than that in the CK treatment, while the dissolved organic $\mathrm{C}: \mathrm{N}$ ratio in the $+\mathrm{C}$ and $-\mathrm{C}$ treatments in the late rice harvesting stage (347 days after chicken grazing) was significantly lower than that in the CK (Fig. 1c).

Soil ammonium and nitrate nitrogen. Throughout the rice growth period, the soil ammonium and nitrate nitrogen in the plots with cover crops were higher than those in the bare fallow field (CK, Fig. 3a,b). The soil ammonium and nitrate nitrogen in the $+\mathrm{C}$ treatment were higher than those in the $-\mathrm{C}$ treatment.

Daily and annual $\mathrm{CH}_{4}$ and $\mathrm{CO}_{2}$ net ecosystem exchange. During the rice growth period, the peak $\mathrm{CO}_{2}$ and $\mathrm{CH}_{4}$ fluxes occurred during the early rice season (Fig. 4). The $\mathrm{CH}_{4}$ fluxes in the plots with cover crops were higher than those in the bare fallow field (CK, Fig. 4b), while the peak $\mathrm{CH}_{4}$ fluxes in the $+\mathrm{C}$ treatment were lower than those in the $-\mathrm{C}$ treatment. The annual $\mathrm{CH}_{4}$ emissions in the $+\mathrm{C}$ treatment were $806.5 \mathrm{~kg} \mathrm{ha}^{-1}$ (Table 2), 10.6\% lower than those in the CK treatment and $26.9 \%$ lower than those in the $-\mathrm{C}$ treatment. The annual $\mathrm{CO}_{2}$ emissions of the $+\mathrm{C}$ treatment were $8,214.0 \mathrm{~kg} \mathrm{ha}^{-1}$, with a significant difference observed between the $+\mathrm{C}$ treatment and the other two treatments. The 100-year global warming potentials (GWPs) of the $+\mathrm{C}$ treatment were $6.2 \%$ lower than those of the $-\mathrm{C}$ treatment (Table 2). Although the GWPs in the plots with cover crops increased by $8.7 \%$ compared with those in the the CK treatment, there was not a significant difference between the plots with cover crops and the CK treatment. 


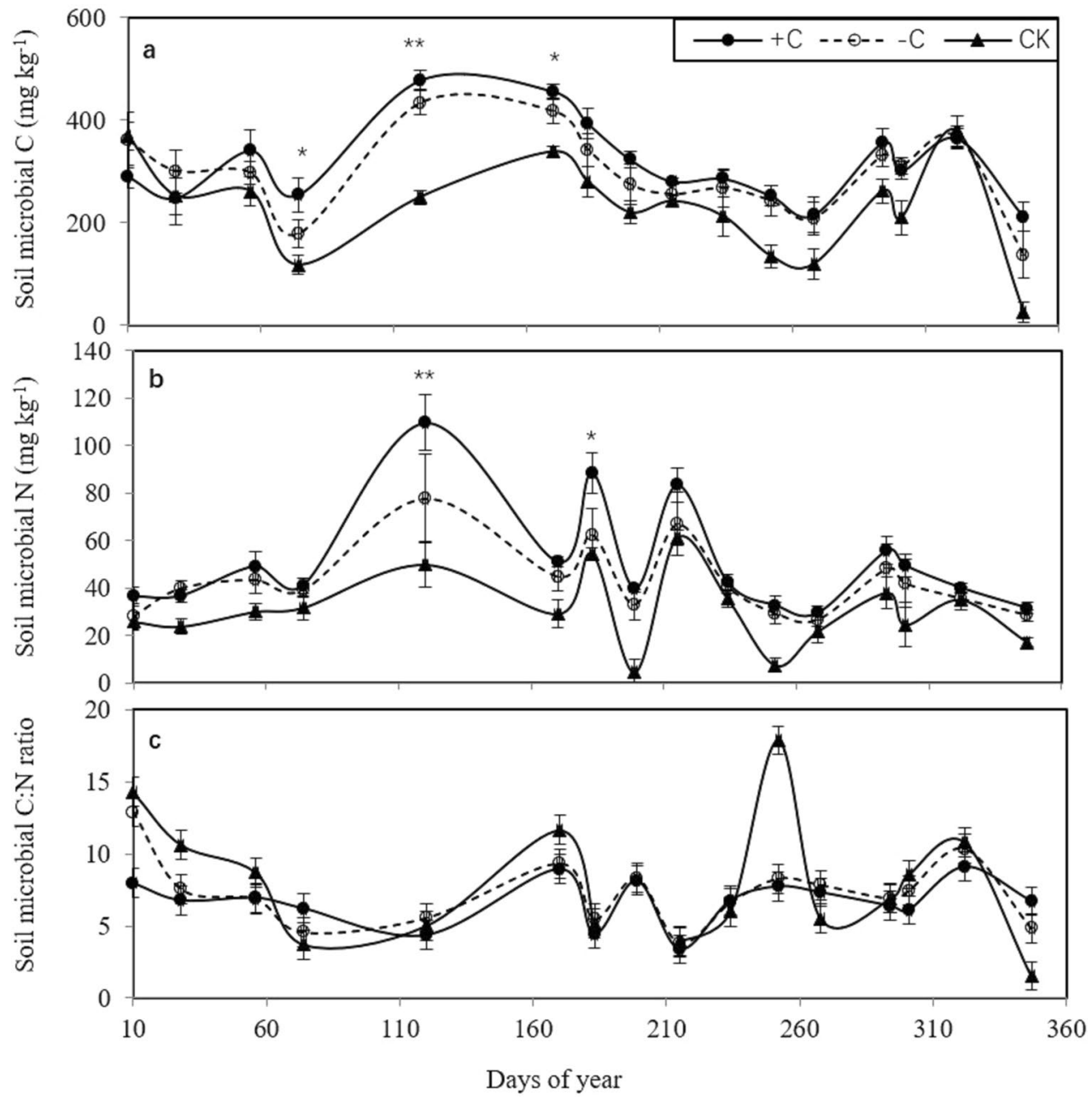

Figure 1. Variation in the soil microbial carbon, nitrogen and C:N ratio among the three treatments (cover crops with chicken grazing $(+\mathrm{C})$, cover crops without chicken grazing $(-\mathrm{C})$, and bare fallow field $(\mathrm{CK}) .^{*},{ }^{* *}$ indicate significant differences at the 0.05 and 0.01 levels, respectively.

GPP, $\mathbf{R}_{\text {eco }}$ and NEE. In the rice growth period, the gross primary production (GPP) in the plots with cover crops and chicken grazing and the plots with cover crops and no chicken grazing was higher than that in the bare fallow field (CK, Fig. 5b). Moreover, the change in ecosystem respiration $\left(\mathrm{R}_{\text {eco }}\right)$ was similar to the change in GPP (Fig. 5a). Except during the late rice harvesting season, the net ecosystem exchanges (NEEs) were shown as $\mathrm{CO}_{2}$ uptake (negative value, Fig. 5c).

Yield. The rice yield in the plots with cover crops and chicken grazing increased by $12.3 \%$ compared with that in the CK treatment (Table 3 ). The yield of the $+\mathrm{C}$ treatment was $3.8 \%$ higher than that of the $-\mathrm{C}$ treatment, but the difference between the $+\mathrm{C}$ treatment and $-\mathrm{C}$ treatments was not significant. For the yield components, a higher number of panicles per unit area $\mathrm{m}^{-2}$ may be the main factor for increasing the rice yield in the plots with cover crops; a significant difference in panicles $\mathrm{m}^{-2}$ existed between the $+\mathrm{C}$ treatment and CK treatment.

\section{Discussion}

The results of this study could be used to reduce inorganic nitrogen fertilization by approximately $33 \%$ compared with the level of inorganic nitrogen applied by Huang et al. ${ }^{6}$ in the same region. Grazing chickens in plots with cover crops $(+\mathrm{C})$ could improve soil carbon and nitrogen transformations and increase the double-season rice grain yield. The winter fallow period is a suitable window for renewing and improving soil fertility in the double-season rice cropping system in southern China. Our results suggest that the $+C$ treatment is an effective measure for improving soil fertility and reducing nitrogen application. It has been recommended to use the cover crops (green manure) planted in winter fallow fields in rice paddy soil ${ }^{5,7}$; however, our data indicated that the total carbon, nitrogen, and labile carbon and nitrogen contents in the $+\mathrm{C}$ treatment were higher than those in the treatment with cover crops alone $(-\mathrm{C})$, and the yield of the $+\mathrm{C}$ treatment was $3.8 \%$ higher than that of the $-\mathrm{C}$ treatment. Therefore, the combination of chicken grazing and cover crops in the winter fallow field is a win-win model for improving soil fertility and increasing rice grain yield while reducing the quantity of 

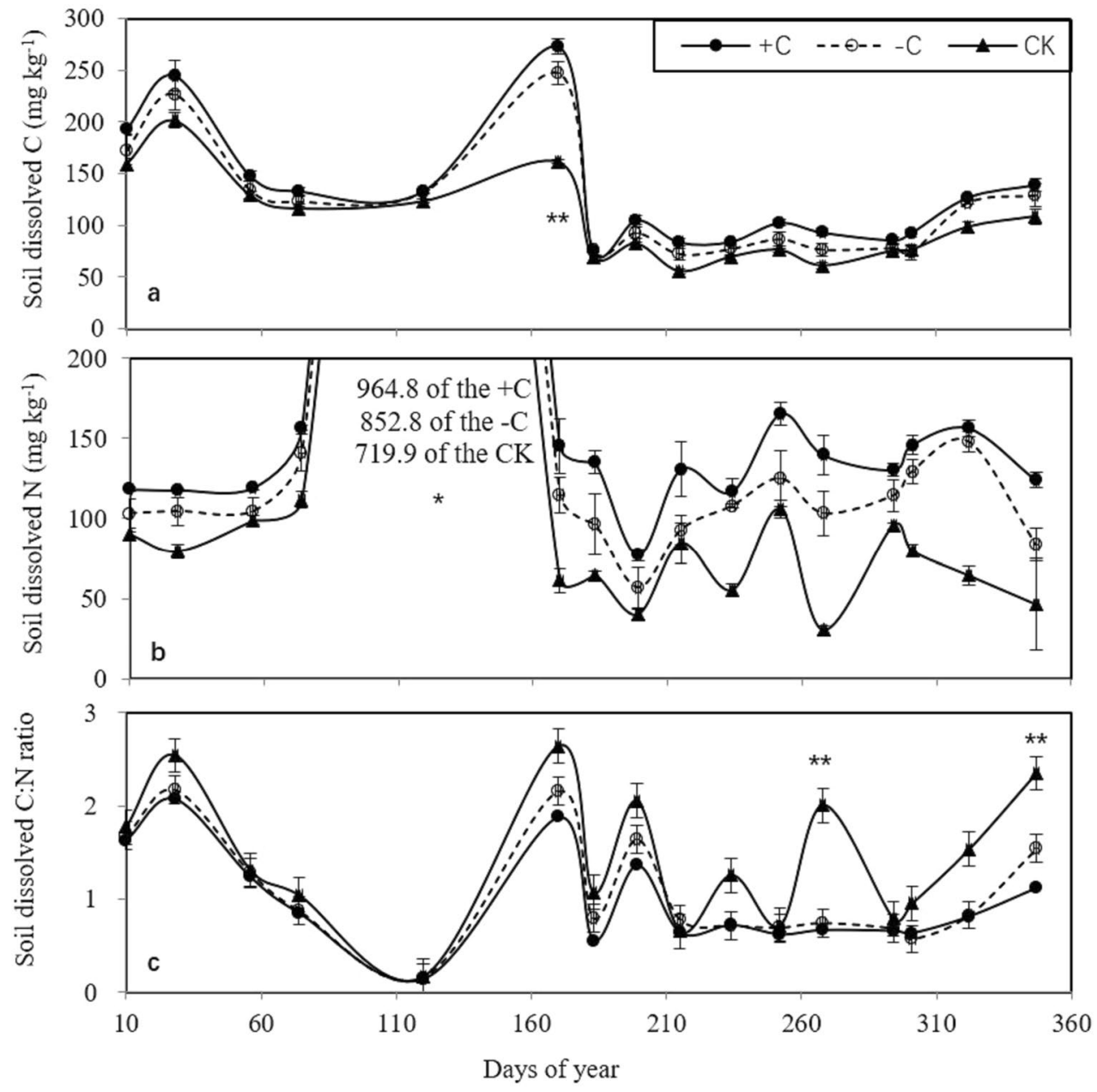

Figure 2. Variation in the soil dissolved nitrogen, carbon and C:N ratio among the three treatments (cover crops with chicken grazing $(+\mathrm{C})$, cover crops without chicken grazing $(-\mathrm{C})$, and bare fallow field $(\mathrm{CK})$. $^{*}{ }^{* *}$ indicate significant differences at the 0.05 and 0.01 levels, respectively.

inorganic nitrogen application. Moreover, using symbiotic farming technologies, such as cover crops and chicken farming, in fallow winter fields promotes green manure applications, because chicken grazing could increase the economic benefits for organic farming.

Organic chicken manure ${ }^{16,17}$ and green manure application significantly increased the contents of labile C and $\mathrm{N}$ measured by dissolved organic carbon (DOC) and dissolved organic nitrogen (DON). DOC and DON affect the supply and effectiveness of nutrients ${ }^{18,19}$. For example, Jones et al. ${ }^{17}$ reported that DON constitutes a major soluble $\mathrm{N}$ pool in most soils and that plant roots have the potential to access some of this pool. Magill and Aber ${ }^{15}$ indicated that labile carbon appears to increase net $\mathrm{N}$ immobilization rather than net $\mathrm{N}$ mineralization. In this study, the DOC in the cover crop treatments in the winter fallow field was higher than that in the CK treatment, and a similar trend was found for the DON. Further, the DOC and DON in the $+\mathrm{C}$ treatment were higher than those in the $-\mathrm{C}$ treatment. Our data suggested that the use of a combination of chicken grazing and cover crops in winter fallow fields could improve the soil nutrient potential and the effectiveness of the nutrients and increase the amount of soil nitrogen available for direct and indirect absorption by plants. Evidence of higher double-season rice yields in the $+\mathrm{C}$ treatment indicated that the use of chicken grazing and cover crops could provide more DON and DOC to the plants.

Fresh manure application and crop straw recycling can cause a significant stimulation of $\mathrm{CH}_{4}$ emissions, as these materials provide abundant and fresh $\mathrm{C}$ sources for $\mathrm{CH}_{4}$ production in aerobic rice fields ${ }^{8,9}$. Our results showed that the $\mathrm{CH}_{4}$ emissions in the $-\mathrm{C}$ treatment were higher than those in the $\mathrm{CK}$ treatment. Taking $\mathrm{CH}_{4}$ and $\mathrm{CO}_{2}$ emissions and crop yields into account, previous studies have suggested that decomposed organic matter, such as biogas residue, can improve long-term soil fertility without an increase in yield-scaled GWPs ${ }^{20,21}$. Our results showed that the $+\mathrm{C}$ treatment had no significant stimulatory effect on the total $\mathrm{CH}_{4}$ emissions, especially in the late rice season. Different exogenous carbon inputs (e.g., fresh manure and/or green manure) could significantly change the abundance and community composition of soil methanogens and methanotrophs. Wang et al. ${ }^{22}$ found that the microbial mechanism associated with the reduction in $\mathrm{CH}_{4}$ emissions in fields amended by biochar was the variation in the soil methanogen to methanotroph abundance ( $m c r A / p m o A$ ratio), which 

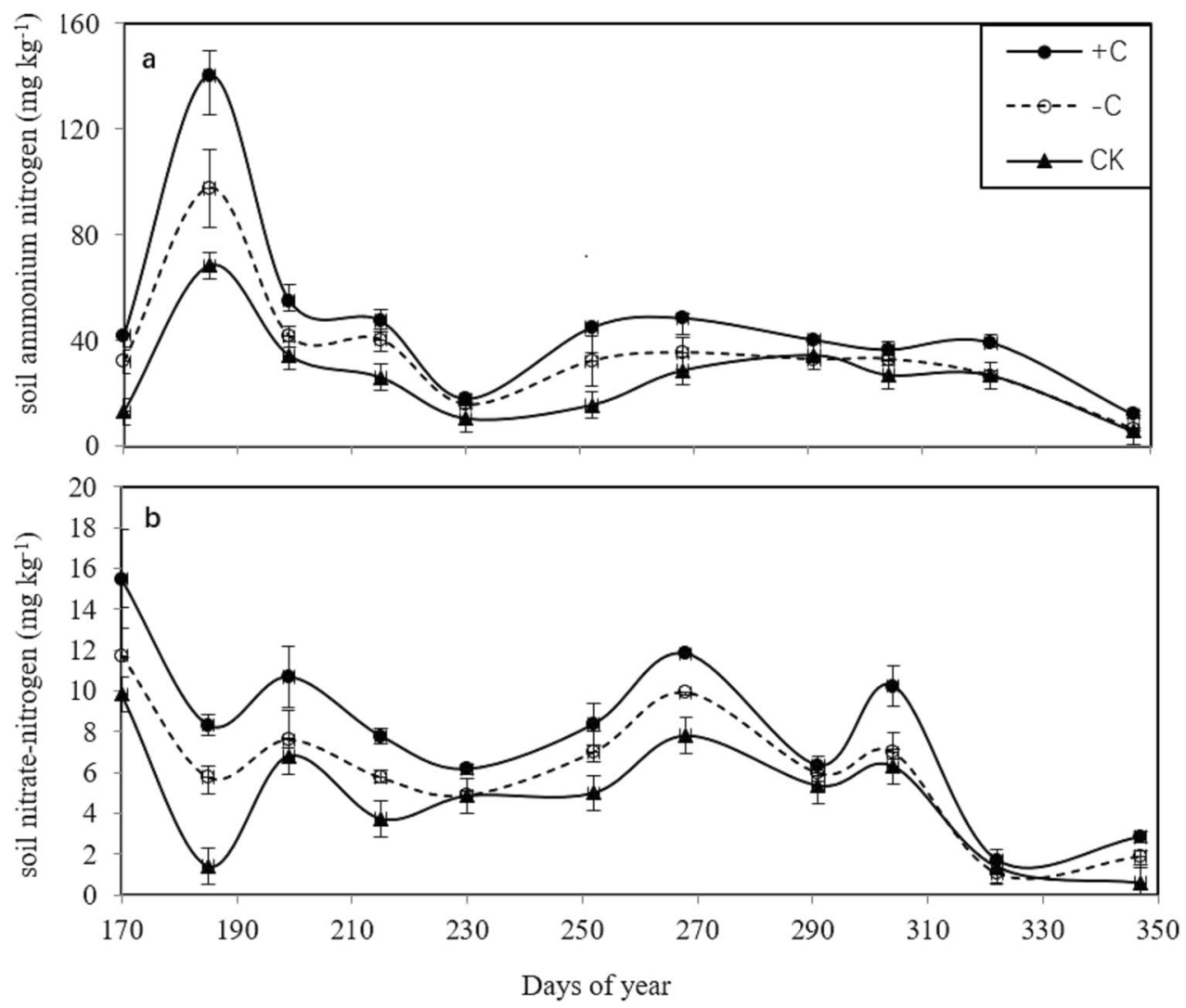

Figure 3. Variation in the soil ammonium nitrogen and nitrate-nitrogen among the three treatments (cover crops with chicken grazing $(+C)$, cover crops without chicken grazing $(-C)$, and bare fallow field $(C K)$.

is mainly ascribed to increased soil $\mathrm{NH}_{4}^{+}$, DOC content, and porosity. Soil DOC could enhance methanotroph growth directly ${ }^{23,24}$. The dynamic determination of soil nutrients in this study also showed that the DOC and soil ammonium in the $+\mathrm{C}$ treatment were higher than those in the $\mathrm{CK}$ treatment. Therefore, the $+\mathrm{C}$ treatment reduced $\mathrm{CH}_{4}$ emissions, probably by providing more labile organic $\mathrm{C}$ compounds and even increasing the abundance of soil methanotrophs.

However, $\mathrm{CH}_{4}$ emissions in the early rice season were significantly higher than those in the late rice season, which was in contrast with the report of Feng et al. ${ }^{21}$. A possible reason was that the exogenous carbon input was concentrated in the early season, and the early rice straw was removed in the late season. In this study, the exogenous carbon input in the early season included rice straw from the previous late season, green manure and chicken manure, and the extra $\mathrm{NH}_{4}^{+}-\mathrm{N}$ and DOC from the exogenous carbon input were exhausted during the early season. The soil Eh and DOC contents were key determinants of the soil $\mathrm{CH}_{4}$ emissions $^{14,25,26}$. On the other hand, the DOC and soil microbial carbon in the early season were higher than those in the late season, and the peak values of DOC and soil microbial carbon were found in the early season, therefore providing higher $\mathrm{C}$ sources for $\mathrm{CH}_{4}$ production in the early season than in the late season. This phenomenon suggested that the early rice season was more suitable than the late rice season for exogenous carbon input. The average air temperature from the transplantation stage to the full-heading stage was $22.8^{\circ} \mathrm{C}$ in the early season and $26.7^{\circ} \mathrm{C}$ in the late season. The soil temperature increased with the average air temperature, although there was not a linear relationship between these variables, and soil temperature increase can cause a significant stimulation of $\mathrm{CH}_{4}$ emissions from rice fields ${ }^{27}$.

\section{Conclusions}

Cover crop-chicken farming in a winter fallow field was an effective model to reduce the amount of carbon emissions and fertilization and significantly improve soil nutrients and rice yields. It provides an alternative technological approach to improve soil fertility under intensified rice cultivation.

\section{Materials and methods}

Experimental site and test cultivars. A field experiment of cover crop planting in a winter fallow field was conducted in Changsha $\left(28^{\circ} 11^{\prime} \mathrm{N}, 113^{\circ} 04^{\prime} \mathrm{E}\right)$, Hunan Province, China, from 2014-2015. The soil in the experimental field was tidal clay, with $1.16 \%$ organic carbon, $0.17 \%$ total $\mathrm{N}$, and a $\mathrm{pH}$ of 6.15 . 

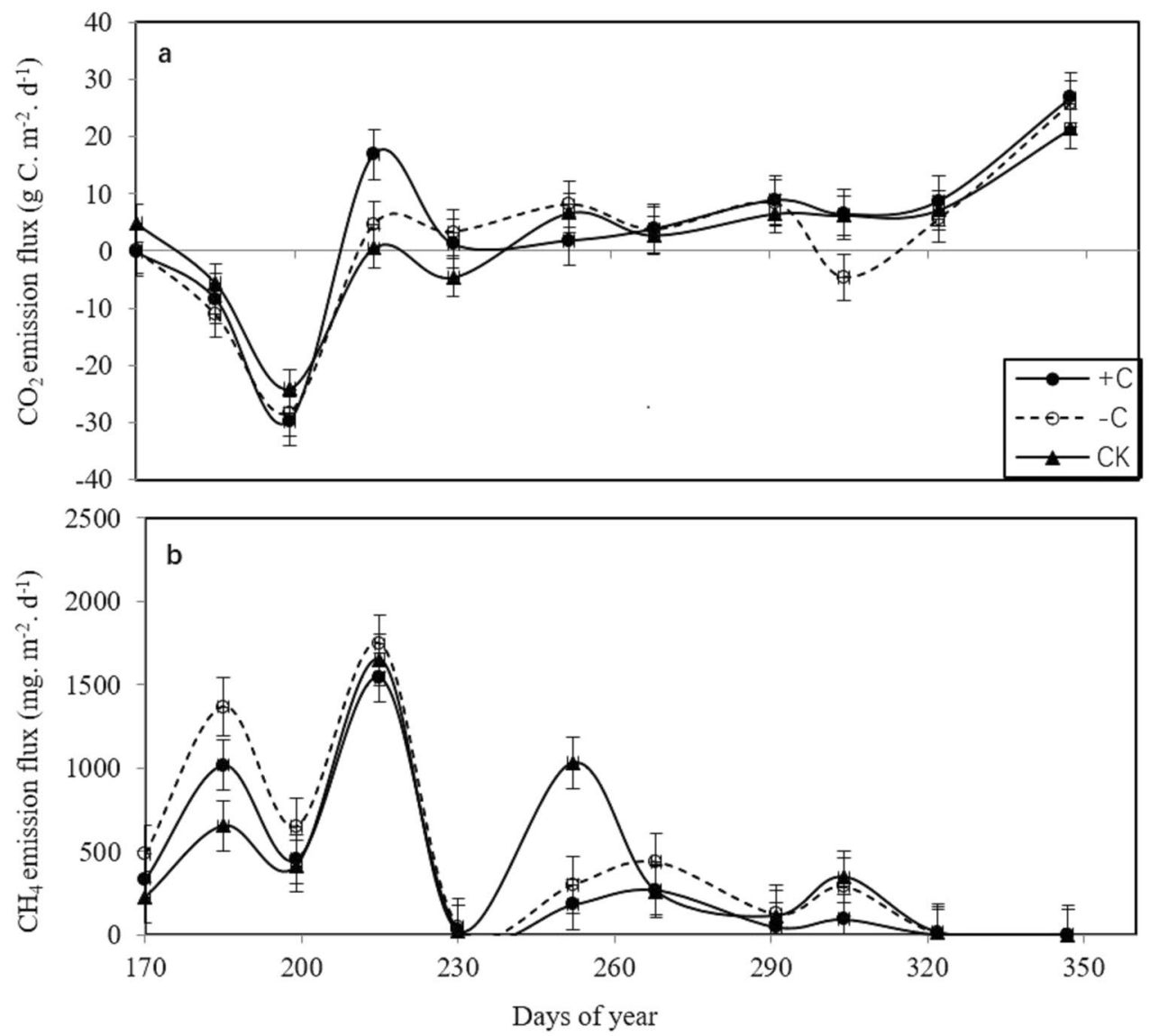

Figure 4. Variation in the $\mathrm{CO}_{2}$ and $\mathrm{CH}_{4}$ fluxes among the three treatments (cover crops with chicken grazing $(+\mathrm{C})$, cover crops without chicken grazing $(-\mathrm{C})$, and bare fallow field $(\mathrm{CK})$.

\begin{tabular}{|c|c|c|c|c|c|c|c|}
\hline \multirow[b]{2}{*}{ Treatment } & \multicolumn{3}{|c|}{$\mathrm{CO}_{2}$ emissions $\left(\mathrm{kg} \mathrm{ha}^{-1}\right)$} & \multicolumn{3}{|c|}{$\mathrm{CH}_{4}$ emissions $\left(\mathrm{kg} \mathrm{ha}^{-1}\right)$} & \multirow{2}{*}{$\begin{array}{l}\text { GWPs } \\
\left(\mathrm{kg} \mathrm{CO}_{2}-\mathrm{eq} \mathrm{ha} \mathrm{h}^{-1}\right)\end{array}$} \\
\hline & Early season & Late season & Total & Early season & Late season & Total & \\
\hline$+\mathrm{C}$ & $-4,208.1 \mathrm{~b}$ & $12,142.2 \mathrm{a}$ & $8,214.0 \mathrm{a}$ & $681.3 \mathrm{a}$ & $125.2 \mathrm{~b}$ & $864.3 \mathrm{~b}$ & $29,820.4 a$ \\
\hline$-\mathrm{C}$ & $-6,888.3 a$ & $9,227.2 \mathrm{a}$ & $2,272.6 \mathrm{c}$ & $857.5 a$ & $246.0 \mathrm{a}$ & $1,180.4 \mathrm{a}$ & $31,783.3 \mathrm{a}$ \\
\hline CK & $-6,113.5 a$ & $10,331.8 \mathrm{a}$ & $4,265.1 \mathrm{~b}$ & $608.6 a$ & $294.0 \mathrm{a}$ & $963.0 \mathrm{a}$ & $28,340.9 a$ \\
\hline
\end{tabular}

Table 2. $\mathrm{CO}_{2}$ and $\mathrm{CH}_{4}$ emissions and their 100 a global warming potentials (GWPs) among the three treatments [cover crops with chicken grazing $(+\mathrm{C})$, cover crops with no chicken grazing $(-\mathrm{C})$, and bare fallow field $(\mathrm{CK})]$. Different lowercase letters in the same column among the different treatments indicate significant differences at the 0.05 level.

Experimental design and field management. A randomized block experiment was established with 3 different treatments, including cover crops (Lolium spp. and Astragalus sinicus) with chicken grazing (+ C), cover crops without chicken grazing $(-\mathrm{C})$, and a bare, fallow field (CK). Each field plot covers $140 \mathrm{~m}^{2}$, and there were three replications. To prevent the movement of water between adjacent plots, ridges were covered with a plastic sheet inserted into the soil to a depth of $0.5 \mathrm{~m}$.

Ryegrass and milk vetch were planted on October 10th, 2014, at seed densities of 23 and $40 \mathrm{~kg} \mathrm{ha}^{-1}$, respectively. Thirty-day-old yellow chickens were introduced into the field on November 25 th. To ensure the homogeneity of the chicken manure inputs, a $3 \mathrm{~m} \times 3 \mathrm{~m}$ cage was used during the process of chicken grazing. There were 30 chickens in each cage. Five kilograms of corn flour was fed to the chickens in each cage daily. The corn flour was $1.8 \%$ nitrogen. The cage was moved every 7 days in the chicken-grass plot until February 2, 2015. The quantity of in situ chicken manure input into the system within the symbiotic period (69 days) in these plots was estimated to be $96.3 \mathrm{t} \mathrm{ha}^{-1}$ by collecting the chicken waste in an underground container. The underground container was a square with a side length of $50 \mathrm{~cm}$ and a height of $10 \mathrm{~cm}$. There were 3 symbiotic periods in these plots, and the chicken waste samples were collected every $12 \mathrm{~h}$ for three days. On March 27th, 2015, the average aboveground biomass of the cover crops was $11.7 \mathrm{t} \mathrm{ha}^{-1}$ in the $+\mathrm{C}$ plot and $14.4 \mathrm{t} \mathrm{ha}^{-1}$ in the $-\mathrm{C}$ plot. All the procedures used in this experiment were conducted in accordance with the Chinese Guidelines for Animal 

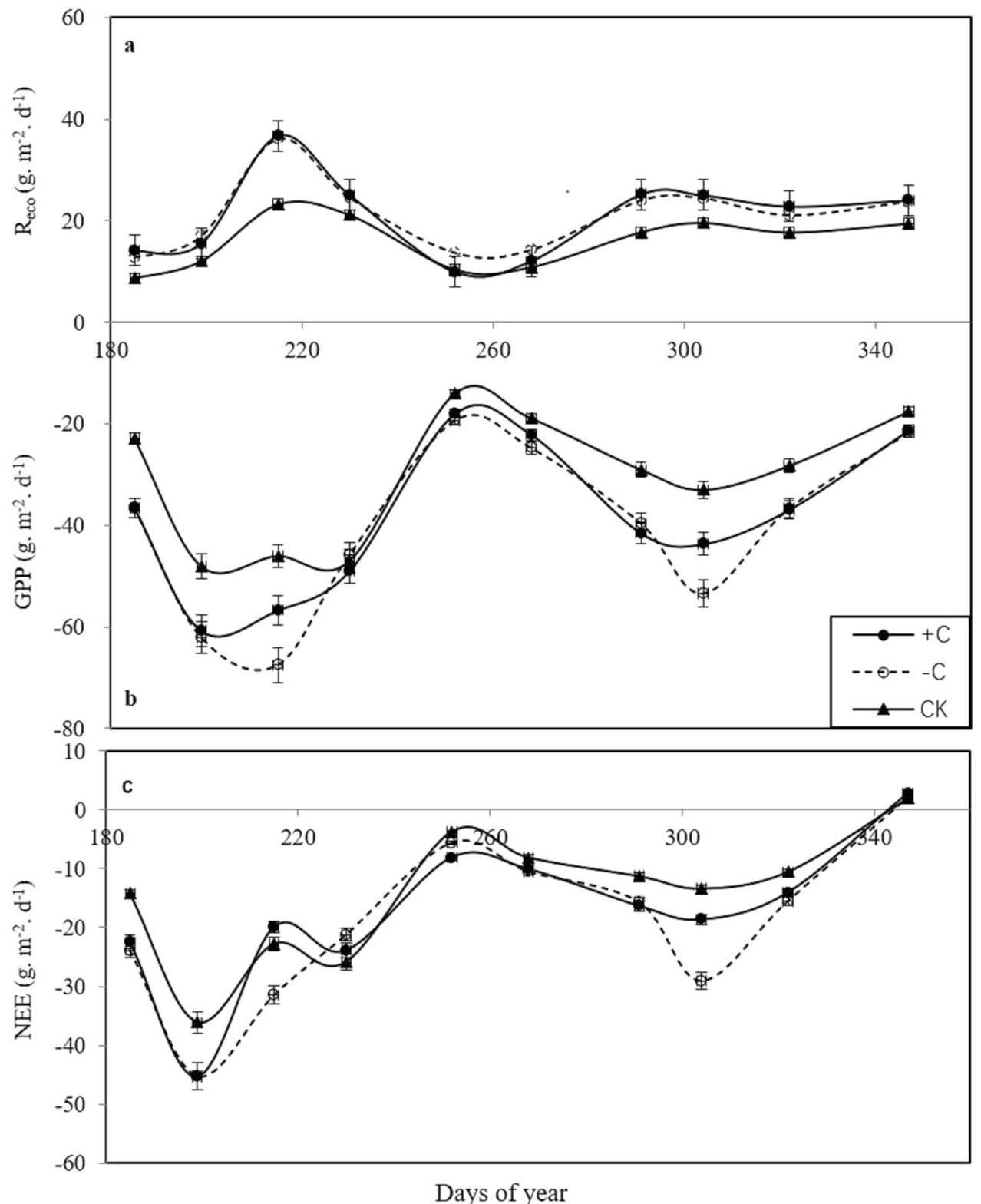

Figure 5. Variation in the gross primary production (GPP), ecosystem respiration $\left(\mathrm{R}_{\mathrm{eco}}\right)$, and net ecosystem exchanges (NEEs) among the three treatments (cover crops with chicken grazing $(+\mathrm{C})$, cover crops without chicken grazing $(-\mathrm{C})$, and bare fallow field (CK).

\begin{tabular}{|l|l|l|l|l|l|l|}
\hline Season & Treatment & Yield $\left(\mathbf{t ~ h a}^{-\mathbf{1}}\right)$ & ${\text { Panicle } \mathbf{~ m}^{-\mathbf{2}}}$ & Spikelets per panicle & Filling ratio (\%) & Grain weight (mg) \\
\hline Early season & $+\mathrm{C}$ & $6.3 \mathrm{a}$ & $306 \mathrm{a}$ & $115 \mathrm{a}$ & $76.1 \mathrm{a}$ & $26.6 \mathrm{a}$ \\
\hline & $-\mathrm{C}$ & $6.1 \mathrm{ab}$ & $282 \mathrm{ab}$ & $118 \mathrm{a}$ & $75.0 \mathrm{a}$ & $26.8 \mathrm{a}$ \\
\hline & CK & $5.6 \mathrm{~b}$ & $245 \mathrm{~b}$ & $113 \mathrm{a}$ & $79.8 \mathrm{a}$ & $27.6 \mathrm{a}$ \\
\hline Late season & $+\mathrm{C}$ & $7.1 \mathrm{a}$ & $411 \mathrm{a}$ & $87 \mathrm{~b}$ & $82.8 \mathrm{a}$ & $27.5 \mathrm{a}$ \\
\hline & $-\mathrm{C}$ & $6.8 \mathrm{a}$ & $364 \mathrm{a}$ & $93 \mathrm{a}$ & $79.9 \mathrm{a}$ & $27.3 \mathrm{a}$ \\
\hline & CK & $6.1 \mathrm{~b}$ & $318 \mathrm{~b}$ & $93 \mathrm{a}$ & $83.6 \mathrm{a}$ & $27.4 \mathrm{a}$ \\
\hline
\end{tabular}

Table 3. Yield and its components among the three treatments [chicken grazing $(+\mathrm{C})$, cover crops with no chicken grazing $(-\mathrm{C})$, and bare fallow field $(\mathrm{CK})]$. Different lowercase letters in the same column among the different treatments indicate significant differences at the 0.05 level. 


\begin{tabular}{|c|c|c|c|c|}
\hline Season & \multicolumn{2}{|c|}{ Cover crops with chicken grazing $(+C)$} & Cover crops without chicken grazing $(-\mathrm{C})$ & Bare fallow field (CK) \\
\hline \multirow{3}{*}{ Winter } & \multirow{3}{*}{ No fertilization } & Oct. 15, 2014: Cover crop seeding & Oct. 15, 2014: Cover crop seeding & Oct. 15, 2014: No cover crop \\
\hline & & Nov. 25, 2014-Feb. 2, 2015: Chicken grazing & & \\
\hline & & Mar. 27, 2015: Tillage & Mar. 27, 2015: Tillage & Mar. 27, 2015: Tillage \\
\hline Early rice & Fertilization & \multicolumn{3}{|c|}{$\begin{array}{l}\text { The amount of fertilizer input was reduced by } 30 \% \text {, and nitrogen was not included in the base fertilizer } \\
\text { May 4, 2015: base fertilizer: } \mathrm{P}_{2} \mathrm{O}_{5} 60 \mathrm{~kg} \cdot \mathrm{ha}^{-1} ; \mathrm{K}_{2} \mathrm{O} 30 \mathrm{~kg} \cdot \mathrm{ha}^{-1} \text {; } \\
\text { May 17, 2015: tiller fertilizer: } \mathrm{N} 51.8 \mathrm{~kg} \cdot \mathrm{ha}^{-1} ; \\
\text { Jun. 16, 2015: panicle fertilizer: } \mathrm{N} 22.2 \mathrm{~kg} \cdot \mathrm{ha}^{-1} ; \mathrm{K} 2 \mathrm{O} 30 \mathrm{~kg} \cdot \mathrm{ha}^{-1}\end{array}$} \\
\hline Late rice & Fertilization & \multicolumn{3}{|c|}{$\begin{array}{l}\text { The amount of fertilizer input was reduced by } 10 \% \text {, and nitrogen was not included in the base fertilizer } \\
\text { Jul. 24, 2015: base fertilizer: } \mathrm{P}_{2} \mathrm{O}_{5} 60 \mathrm{~kg} \cdot \mathrm{ha}^{-1} ; \mathrm{K} 2 \mathrm{O} 30 \mathrm{~kg} \cdot \mathrm{ha}^{-1} \text {; } \\
\text { Aug. 3, 2015: tiller fertilizer: } \mathrm{N} 51.0 \mathrm{~kg} \cdot \mathrm{ha}^{-1} ; \\
\text { Aug. 30, 2015: panicle fertilizer: } \mathrm{N} 30.6 \mathrm{~kg} \cdot \mathrm{ha}^{-1} ; \mathrm{K}_{2} \mathrm{O} 30 \mathrm{~kg} \cdot \mathrm{ha}^{-1} \text {; } \\
\text { Sep. 12, 2015: grain fertilizer: } \mathrm{N} 20.4 \mathrm{~kg} \cdot \mathrm{ha}^{-1}\end{array}$} \\
\hline
\end{tabular}

Table 4. Experimental design ${ }^{16}$.

Welfare. The experimental procedures performed in the current study were approved by the Hunan Agricultural University Institutional Animal Care and Use Committee (Changsha, China). Furthermore, all the experimental protocols, including animal handling, were performed humanly, and animal welfare was specially considered. We further confirmed that no animals were harmed or stressed during the experimental period.

The cover crops were incorporated into the soil on March 27th, and all the plots were used to grow doubleseason rice. The early rice cultivar 'Zhongjiazao 17' and the late rice cultivar 'Xiangwanxian 12' were used in the experiment, and their growth durations were 109 days and 115 days, respectively. Rice seedlings were transplanted on May 5th and harvested on July 12th for the early-season rice, followed by the late-season rice, which was transplanted on July 25 th and harvested on October 30 th. The seedlings were 35 and 25 days old in the early and late seasons, respectively. The transplantation density was 30 hills $\mathrm{m}^{-2}$ for the early rice season and 25 hills $\mathrm{m}^{-2}$ for the late rice season.

We supplied nitrogen $(\mathrm{N})$ in the form of urea, calcium superphosphate for phosphorus pentoxide $\left(\mathrm{P}_{2} \mathrm{O}_{5}\right)$, and potassium chloride for potassium oxide $\left(\mathrm{K}_{2} \mathrm{O}\right)$ in the rice growing season. The quantity of $\mathrm{N}$ supplied was $74 \mathrm{~kg} \mathrm{ha}^{-1}$ in the early rice season and $102 \mathrm{~kg} \mathrm{ha}^{-1}$ in the late rice season. Urea was applied three times during the rice season; the ratio of tillering fertilizer to panicle fertilizer (grain fertilizer) was 70:30 in the early rice season and 50:50 in the late rice season. The quantity of $\mathrm{P}_{2} \mathrm{O}_{5}$ and $\mathrm{K}_{2} \mathrm{O}$ supplied was $60 \mathrm{~kg} \mathrm{ha}^{-1}$, and the same quantity was applied in both seasons. Potassium chloride was applied twice during the rice season, $50 \%$ as basal fertilizer and $50 \%$ as tillering fertilizer. The calcium superphosphate was applied as a basal fertilizer before transplantation. Water management was performed according to the technology used for double rice cropping systems (local high-yield cultivation) (Table 4).

Soil chemical properties. Soil samples from the $0-20 \mathrm{~cm}$ soil layer were used to determine the soil chemical properties. The samples were collected during cover crop harvesting, early rice harvesting and late rice harvesting. The soil samples were air dried and the soil organic matter was determined using $\mathrm{K}_{2} \mathrm{Cr}_{2} \mathrm{O}_{7}$ and concentrated $\mathrm{H}_{2} \mathrm{SO}_{4}$ and heating. The soil total $\mathrm{N}$ was determined with the Kjeldahl method, which involved two steps: (1) the digestion of the samples to convert organic $\mathrm{N}$ into $\mathrm{NH}_{4}^{+}-\mathrm{N}$ and (2) the determination of $\mathrm{NH}_{4}^{+}-\mathrm{N}$ in the digest. The soil C:N ratio was calculated by dividing the SOC concentration by the TN concentration. Soil ammonium $\mathrm{N}$ was analyzed using indophenol blue colorimetry. Soil nitrate-N was analyzed using ultraviolet spectrophotometry.

In situ $\mathrm{CH}_{4}$ and $\mathrm{CO}_{2}$ flux measurements. During the rice growing season, in situ $\mathrm{CH}_{4}$ and $\mathrm{CO}_{2}$ flux were measured with a static chamber by circulating the gas within the chamber and pipes of an ultraportable greenhouse gas analyzer $\left(\mathrm{CH}_{4} / \mathrm{CO}_{2} / \mathrm{H}_{2} \mathrm{O}\right.$ Analyzer; Los Gatos Research Corp., USA). The static chamber was a square with a side length of $50 \mathrm{~cm}$ and a height of $120 \mathrm{~cm}$. A fluted base consistent with the static chamber was inserted in the soil in advance. On the sampling dates, daytime samples were collected from 9:00-11:00 a.m. and 15:00-17:00 p.m., and nighttime samples were collected from 19:00-21.00 p.m. The testing time in each plot was $5 \mathrm{~min}$. The sampling dates were 170, 185, 199, 215, 230, 252, 268, 291, 304, 322, and 347 days after the chickens were introduced into the field. The samples were collected at intervals of 14 days, plus or minus one day if the weather forecast for a sampling date was rainy.

The temperature inside the static chamber needs to be accurately recorded at a soil depth of $3 \mathrm{~cm}$. Plants (excluding the border plants) were sampled from a $0.24 \mathrm{~m}^{2}$ area of each plot on the sampling date. The plant samples were manually separated into leaf and straw and/or grains. The volume of the plant samples was measured with drainage. The effective volume in the chamber was reduced to subtract the internal plant volume from the chamber. The leaf area was determined with a leaf area meter (LI-3000A, LICOR, Lincoln, NE, USA). Lastly, the plant samples were oven-dried at $70^{\circ} \mathrm{C}$ to constant weight to determine the aboveground biomass.

The $\mathrm{CO}_{2}\left(\mathrm{~F}, \mathrm{~g} \mathrm{~m}^{-2}\right.$ day $\left.^{-1}\right)$ and $\mathrm{CH}_{4}\left(\mathrm{~F}, \mathrm{mg} \mathrm{m}^{-2}\right.$ day $\left.^{-1}\right)$ fluxes were calculated using the following formula (Eq. 1):

$$
\mathrm{F}=\frac{\mathrm{P} \times \mathrm{V}}{\mathrm{R} \times \mathrm{A} \times(\mathrm{T}+273.15)} \times \frac{\mathrm{dc}}{\mathrm{dt}},
$$


where $\mathrm{P}$ is the atmospheric pressure under standard conditions $\left(101.2237 \times 10^{3} \mathrm{~Pa}\right)$; $\mathrm{V}$ is the effective volume in the chamber $\left(\mathrm{m}^{3}\right)$, the difference between the volume of the static chamber and the volume of the plant, fan and temperature recorder; $\mathrm{R}$ is a gas constant $\left(8.3144 \mathrm{~J} \cdot \mathrm{mol}^{-1} \mathrm{~K}^{-1}\right)$; $\mathrm{A}$ is the area of the chamber cover $\left(\mathrm{m}^{2}\right)$; $\mathrm{T}$ is the average temperature at testing time inside the chamber $\left({ }^{\circ} \mathrm{C}\right)$; and $\mathrm{dc} / \mathrm{dt}$ is the rate of change in the concentration of $\mathrm{CO}_{2}$ and $\mathrm{CH}_{4}$.

To accurately calculate the $\mathrm{CO}_{2}$ and $\mathrm{CH}_{4}$ fluxes in the paddy field, the daytime and nighttime $\mathrm{CO}_{2}$ and $\mathrm{CH}_{4}$ fluxes on the sampling dates were calculated using the following formulas (Eq. 2-4):

$$
\begin{gathered}
\mathrm{F}_{\text {daytime }}=\mathrm{S}_{\text {daytime }} \times \mathrm{M} \times\left(\mathrm{F}_{1}+\mathrm{F}_{2}\right) / 2, \\
\mathrm{~F}_{\text {night }}=\mathrm{F}_{3} \times \mathrm{S}_{\text {night }} \times \mathrm{M}, \\
\mathrm{F}_{\text {day }}=\mathrm{F}_{\text {daytime }}+\mathrm{F}_{\text {night }},
\end{gathered}
$$

where $F_{1}, F_{2}$ and $F_{3}$ represent the values at 9:00-11:00 a.m. and 15:00-17:00 p.m. on sunny days and 19:00-21:00 p.m., respectively; $\mathrm{S}$ is the day length $\left(\mathrm{s} \mathrm{day}^{-1}\right)$ on the sampling date; and $\mathrm{M}$ is the relative molecular mass of $\mathrm{CO}_{2}$ or $\mathrm{CH}_{4}\left(\mathrm{~g} \mathrm{~mol}^{-1}\right)$.

Seasonal emissions in $\mathrm{CO}_{2}$ and $\mathrm{CH}_{4}$ were calculated using the following formula (Eq. 5):

$$
\mathrm{T}=\mathrm{a} \times 10 \times\left(\sum_{\mathrm{i}=1}^{\mathrm{n}}\left[\frac{\mathrm{F}_{\mathrm{i}}+\mathrm{F}_{\mathrm{i}+1}}{2}\left(\mathrm{t}_{\mathrm{i}+1}-\mathrm{t}_{\mathrm{i}}\right)\right]+\frac{\mathrm{F}_{\mathrm{i}}+\mathrm{F}_{\mathrm{n}}}{2}\right),
$$

where $\mathrm{T}\left(\mathrm{g} \mathrm{m}^{-2}\right)$ is the total seasonal emissions, $\mathrm{F}_{\mathrm{i}}$ and $\mathrm{F}_{\mathrm{i}+1}$ are the measured fluxes on two consecutive sampling days, $t_{i+1}-t_{i}$ is the number of days between the two sampling dates, 10 is the conversion coefficient from $\mathrm{g} \mathrm{m}^{-2}$ to $\mathrm{kg} \mathrm{ha}^{-1}$, and a is the conversion coefficient of the rice growth period (86/61 in the early season and 132/96 in the late season).

In addition, the period from early rice harvesting to late rice transplanting is 13 days. The emissions were calculated using the following formula (Eq. 6):

$$
\mathrm{T}_{\mathrm{ER}-\mathrm{LR}}=\mathrm{T}_{\mathrm{ER}} / 86 \times 6.5+\mathrm{T}_{\mathrm{LR}} / 132 \times 6.5,
$$

where $\mathrm{T}_{\mathrm{ER}-\mathrm{LR}}\left(\mathrm{g} \mathrm{m}^{-2}\right)$ is the total emissions from early rice harvesting to late rice transplanting, $\mathrm{T}_{\mathrm{ER}}$ and $\mathrm{T}_{\mathrm{LR}}$ are the total seasonal emissions in the early rice season and late rice season, respectively, and 86 and 132 are the number of days from sowing to harvesting in the early rice season and late rice season, respectively.

Soil microbe and dissolved carbon and nitrogen measurements. In 2014, soil was sampled from the $0-20 \mathrm{~cm}$ soil layer, and the sampling dates were $10,28,56,74,120,170,183,199,215,234,252,268,294,301$, 322, and 347 days after chicken grazing. Fresh soil samples were taken to determine the soil microbial carbon and nitrogen contents by chloroform fumigation-incubation and $\mathrm{K}_{2} \mathrm{SO}_{4}$ extraction. Soil microbial carbon (SMC, $\left.\mathrm{mg} \mathrm{kg}^{-1}\right)=\mathrm{EC} / 0.38$ and soil microbial nitrogen $\left(\mathrm{SMN}, \mathrm{mg} \mathrm{kg}^{-1}\right)=\mathrm{EN} \times 0.45$, where 0.33 and 0.45 are the conversion coefficients of SMC and SMN, respectively. EC and EN are the differences in organic carbon and nitrogen between fumigation and nonfumigation based $\mathrm{K}_{2} \mathrm{SO}_{4}$ extraction. In addition, other fresh soil samples were used to determine the soil dissolved carbon and nitrogen by $\mathrm{K}_{2} \mathrm{SO}_{4}$ extraction.

Yield and its components. When the rice was mature, 10 hills were sampled randomly from a $5 \mathrm{~m}^{2}$ harvest area to determine the yield components. Panicle number was counted on each hill to determine the panicle number per $\mathrm{m}^{2}$. The panicles were hand-threshed, and the filled spikelets were separated from the unfilled spikelets by submerging them in tap water. Three subsamples of $30 \mathrm{~g}$ of filled spikelets and $3 \mathrm{~g}$ of unfilled spikelets were taken to count the number of spikelets. Based on the spikelets per panicle, the grain-filling percentage $(100 \times$ filled spikelet number/total spikelet number) was determined. The grain yield was determined from a $5 \mathrm{~m}^{2}$ area in each plot and adjusted to the standard moisture content of $0.14 \mathrm{~g} \mathrm{H}_{2} \mathrm{O} \mathrm{g} \mathrm{g}^{-1}$.

Data analysis. The global warming potential (GWP) was the overall GWP of $\mathrm{CH}_{4}$ and $\mathrm{N}_{2} \mathrm{O}$ emissions per unit rice field (ha). The 100-year radiative forcing potential coefficients relative to $\mathrm{CO}_{2}$ were 25 and 298 for $\mathrm{CH}_{4}$ and $\mathrm{N}_{2} \mathrm{O}$, respectively (IPCC, 2007). The net ecosystem exchange (NEE) was the value of $\mathrm{F}_{\text {daytime }}$, ecosystem respiration $\left(\mathrm{R}_{\text {eco }}\right)$ was the value of $\mathrm{F}_{\text {nighttime }}$, and gross primary production (GPP) was the sum of the NEE and $\mathrm{R}_{\mathrm{eco}}$. The means of the indexes were organized in Excel 2016. The SD (standard deviation) of the indexes were determined by descriptive statistics with a $95 \%$ confidence interval. Analysis of variance (ANOVA) and multiple comparisons were performed using Statistix ver. 8.0 (2004) to evaluate the effects of planting cover crops and chicken grazing on the SOC, STN, C:N ratio, DOC, DON, SMN, SMC, and grain yield and its components.

Received: 16 July 2019; Accepted: 7 July 2020

Published online: 28 July 2020

\section{References}

1. Xie, Z. L., Zhang, T. F., Chen, X. Z. \& Zhang, J. G. A study on the nutrient value of oat and its influences on soil fertility of winter fallow fields. Acta Pratacult. Sin. 22(2), 47-53 (2013). 
2. Lal, R. Residue management, conservation tillage and soil restoration for mitigating greenhouse effect by $\mathrm{CO}_{2}$-enrichment. Soil Till. Res. 43, 81-107 (1997).

3. Nambiar, K. K. M. Major cropping systems in India. In Agricultural Sustainability: Economic, Environmental and Statistical Considerations (eds Barnett, B. et al.) 133-169 (Wiley, New York, 1995).

4. Reddy, M. N. \& Krishnaiah, K. Current status if crop response to fertilizers in different agro-climatic regions-experience of the all India coordinated rice improvement project. Fertil. News 44, 113-126 (1999).

5. Elfstrand, S., Hedlund, K. \& Mårtensson, A. Soil enzyme activities, microbial community composition and function after 47 years of continuous green manuring. Appl. Soil Ecol. 35, 610-621 (2007).

6. Singh, S., Singh, J. \& Kashyap, A. Methane flux from irrigated rice fields in relation to crop growth and N-fertilization. Soil Biol. Biochem. 31, 1219-1228 (1999).

7. Cho, Y. S., Mineta, T. \& Hidaka, K. Nitrogen fixation and utilization for green manure of common wild legume narrow leaf vetch (Vicia angustifolia L.). Jpn. Agric. Res. Q. 37, 45-52 (2003).

8. Huang, M., Chen, J. N., Cao, F. B. \& Zou, Y. B. Increased hill density can compensate for yield loss from reduced nitrogen input in machine-transplanted double-cropped rice. Field Crops Res. 221, 333-338 (2018).

9. Kim, S. Y., Gutierrez, J. \& Kim, P. J. Considering winter cover crop selection as green manure to control methane emission during rice cultivation in paddy soil. Agric. Ecosyst. Environ. 161, 130-136 (2012).

10. Wang, Z. Y. et al. A four-year record of methane emissions from irrigated rice fields in the Beijing region of China. Nutr. Cycl. Agroecosyst. 58, 55-63 (2000).

11. Ma, J., Ma, E. D., Xu, H., Yagi, K. \& Cai, Z. C. Wheat straw management affects $\mathrm{CH}_{4}$ and $\mathrm{N}_{2} \mathrm{O}$ emissions from rice fields. Soil Biol. Biochem. 41, 1022-1028 (2009).

12. Ye, R. Z., Doane, T. A., Morris, J. \& Horwath, W. R. The effect of rice straw on the priming of soil organic matter and methane production in peat soils. Soil Biol. Biochem. 81, 98-107 (2015).

13. Wang, $\mathrm{N}$. et al. Straw enhanced $\mathrm{CO}_{2}$ and $\mathrm{CH}_{4}$ but decreased $\mathrm{N}_{2} \mathrm{O}$ emissions from flooded paddy soils: Changes in microbial community compositions. Atmos. Environ. 174, 171-179 (2018).

14. Zheng, H. B. et al. Traditional symbiotic farming technology in China promotes the sustainability of a flooded rice production system. Sustain. Sci. 12, 155-161 (2017).

15. Zhang, L. et al. Integrating cover crops with chicken grazing to improve soil nitrogen in rice fields and increase economic output. Total Environ. Sci. https://doi.org/10.1016/j.scitotenv.2019.135218 (2019).

16. Witter, E., Mårtensson, A. M. \& Garcia, F. V. Size of the soil microbial biomass in a Long-term field experiment as affected by different n-fertilizers and organic manures. Soil Biol. Biochem. 25, 659-669 (1993).

17. Cai, F., Feng, Z. J. \& Zhu, L. Z. Effects of biochar on $\mathrm{CH}_{4}$ emission with straw application on paddy soil. J. Soils Sediments 18, 599-609 (2017).

18. Magill, A. H. \& Aber, J. D. Variation in soil net mineralization rates with dissolved organic carbon additions. Soil Biol. Biochem. 32, 597-601 (2000).

19. Jones, D. L., Healey, J. R., Willett, V. B., Farrar, J. F. \& Hodge, A. Dissolved organic nitrogen uptake by plants: An important N uptake pathway?. Soil Biol. Biochem. 37, 413-423 (2005).

20. Lu, W. F. et al. Methane emissions and mitigation options in irrigated rice fields in southeast China. Nutr. Cycl. Agroecosyst. 58, 65-73 (2000).

21. Feng, J. F. et al. Agriculture, ecosystems and environment impacts of cropping practices on yield-scaled greenhouse gas emissions from rice fields in China: A meta-analysis. Agric. Ecosyst. Environ. 164, 220-228 (2013).

22. Wang, C. et al. Microbial mechanisms in the reduction of $\mathrm{CH}_{4}$ emission from double rice cropping system amended by biochar: A four-year study. Soil Biol. Biochem. 135, 251-263 (2019).

23. Imet, J., Lee, S., Yoon, S., DiSpirito, A. A. \& Semrau, J. D. Characterization of a novel facultative methylocystis species capable of growth on methane, acetate and ethanol. Environ. Microbiol. Rep. 3, 174-181 (2011).

24. Semrau, J. D., Di Spirito, A. A. \& Vuilleumier, S. Facultative methanotrophy: Falseleads, true results, and suggestions for future research. FEMS Microbiol. Lett. 323, 1-12 (2011).

25. Segers, R. Methane production and methane consumption: A review of processes underlying wetland methane fluxes. Biogeochem. 41, 23-51 (1998).

26. Le, M. J. \& Roger, P. Production, oxidation, emission and consumption of methane by soils: A review. Eur. J. Soil Biol. 37, 25-50 (2001).

27. Parashar, D. C., Gupta, P. K., Rai, J., Sharma, R. C. \& Singh, N. Effect of soil temperature on methane emission from paddy fields. Chemosphere 26, 247-250 (1993).

\section{Acknowledgements}

We are thankful to anonymous reviewers and editors for their helpful comments and suggestions. This study was supported by the Earmarked Fund for China Agriculture Research System (CARS-01-26), the China-UK joint Red Soil Critical Zone project from the National Natural Science Foundation of China (Grant No. 41571130053), and Hunan "A Hundred Scholars" Program.

\section{Author contributions}

H.B.Z., H.Q.X. and J.W.T. wrote the manuscript. H.B.Z., L.H.Z., J.B.W., Y.B.Z. and Q.Y.T. collected and organized data. J.W.T. and H.Q.X. acted as corresponding authors. All authors read and approved of the final manuscript.

\section{Competing interests}

The authors declare no competing interests.

\section{Additional information}

Correspondence and requests for materials should be addressed to J.T. or H.X.

Reprints and permissions information is available at www.nature.com/reprints.

Publisher's note Springer Nature remains neutral with regard to jurisdictional claims in published maps and institutional affiliations. 
(c) (i) Open Access This article is licensed under a Creative Commons Attribution 4.0 International cc) License, which permits use, sharing, adaptation, distribution and reproduction in any medium or format, as long as you give appropriate credit to the original author(s) and the source, provide a link to the Creative Commons license, and indicate if changes were made. The images or other third party material in this article are included in the article's Creative Commons license, unless indicated otherwise in a credit line to the material. If material is not included in the article's Creative Commons license and your intended use is not permitted by statutory regulation or exceeds the permitted use, you will need to obtain permission directly from the copyright holder. To view a copy of this license, visit http://creativecommons.org/licenses/by/4.0/.

(C) The Author(s) 2020 